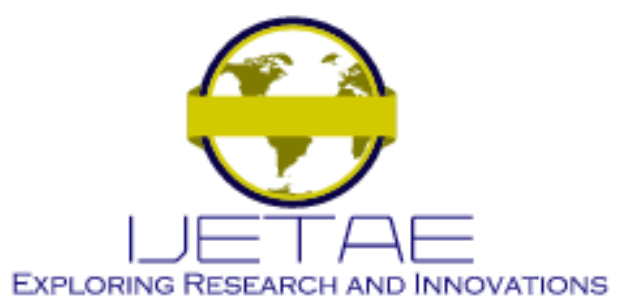

International Journal of Emerging Technology and Advanced Engineering

Website: www.ijetae.com (E-ISSN 2250-2459, Scopus Indexed, ISO 9001:2008 Certified Journal, Volume 11, Issue 11, November 2021)

\title{
Automatic Fire Detection and Extinction with Infrared Multispectrum Electro-Optical Technology with Watch-Dog Timer Control, for a 220KV to 33KV Transformer
}

\author{
Yesica Pamela Leandro Chacon ${ }^{1}$, Omar Chamorro-Atalaya ${ }^{2}$ \\ ${ }^{1,2}$ National Technological University of Lima Sur (UNTELS), Sector 3 Group 1A-03, Villa El Salvador, Lima, Perú
}

\begin{abstract}
The present research aims to design an automatic fire detection and extinction system, developed with infrared multi-spectrum electro-optical technology with watch-dog timer control, for an electrical transformer from $220 \mathrm{KV}$ to $33 \mathrm{KV}$. Upon its development, it is concluded that the automatic detection and extinction system has a deluge system with sprayed water, which will be activated by a detection system with flame sensors, this system has infrared multispectrum Electro-Optical Technology and will be controlled by through the Timer Watch-Dog, which will automatically detect and report any failure in the state-of-theart microprocessor. By subjecting the detection and extinguishing system to operational and functional tests, an optimal response of the deluge sprinklers was obtained, through the pressure and flow parameters, also a coefficient of determination $R^{2}$ equal to 0.991 is obtained, which represents that the design is optimal, evidencing feasibility from the operational and functional point of view.
\end{abstract}

Keywords - Detection, Extinction, Automatic, ElectroOptical, Multispectral, Infrared, Timer Watch-Dog, Transformer

\section{INTRODUCTION}

Electrical transformers, due to their nature of how they have been built and manufactured, internally contain fuel, as well as refrigerants whose calorific value of these are decisive for the generation of a possible ignition of a fire [1]. In a scenario in which a fire is generated in a transformer, it is evident that it will develop a deflagration of very important dimensions, which can seriously affect the room that stores this equipment, as well as the other interior parts of the substation [2,3]. Another aspect to consider that is linked to the fire in this type of electrical substation is the explosion, which would also affect external facilities near or adjacent to the transformer $[4,5]$.
Highlighting the consequences associated with a fire scenario in this type of facility, it is possible to consider the interruption of electrical energy and the impact on the supply to the population or community, in their daily activities, and that even a possible replacement could represent, times dead from operations, as well as high economic losses [6]. Then the need and importance of the implementation of fire protection systems in facilities containing electrical transformers is evident; and in general nowadays it is essential that every type of installation has a fire detection, extinction and alert system [7, 8, 9]. One of the international standards used in Latin America, which regulates fire protection systems internationally is the NFPA 14 and NFPA 15 standard, which specifically specify the technical criteria in order to establish the location of the components in a fire protection system fire (sensors and sprinklers) [10,11]. The safety standards in electrical transformers currently require a strict control of the dimensioning of the mechanical, electrical, and control infrastructure, which guarantee the response speed of the fire, smoke, spark, or thermal sensation detectors or sensors, as well as optimal pressure and flow values, linked to the operation of the sprinklers $[12,13,14]$. In the search to achieve the implementation of fire protection systems according to the degree or level of risk of the components exposed to the possible fire event, it is that, in low, medium or high voltage electrical installations, such as transformers electrical systems from $220 \mathrm{KV}$ to $33 \mathrm{KV}$, use of technologies such as the automation of sensors and actuators through programmable logic controllers and wireless detection systems $[15,16]$. 


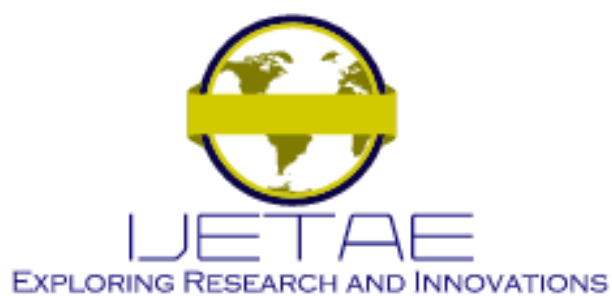

International Journal of Emerging Technology and Advanced Engineering

Website: www.ijetae.com (E-ISSN 2250-2459, Scopus Indexed, ISO 9001:2008 Certified Journal, Volume 11, Issue 11, November 2021)

However, the automatic control is associated with the sensors or elements capturing the fire event $[17,18]$; Thus, with the advancement of technology, sensors with multispectrum infrared electro-optical technology are being used, since they present a high sensitivity, they are activated by the influence of combustion products on the flow (darkening) or the diffusion of light (Tyndall effect) in the infrared, visible and ultraviolet areas of the electromagnetic spectrum [19,20]. In this regard, in [21] it is highlighted that this type of sensor is made up of a transmitter terminal and another receiver, that when the viewing space is darkened due to smoke, only a fraction of light reaches the receiver, thus causing that the electrical signal produced by this is weaker and the alarm is activated [22]. Thus, both the controller and the sensors are associated or linked, generating synergy with the actuating elements (valves and sprinklers) in order to show speed of activation in the presence of the disaster or fire event, this is how the watch-dog technology, with the purpose that through a non-volatile memory the programming of the control system will be loaded for the case of special programs file and a watch-dog timer circuit that detects and reports any failure in the microprocessor; this under a contingency or redundancy system approach [23,24].

Based on what has been previously described, this article describes the results and findings obtained as part of the design of an automatic fire detection and extinguishing system, developed with infrared multi-spectrum electrooptical technology with timer watch-dog control, for an electrical transformer of $220 \mathrm{KV}$ to $33 \mathrm{KV}$; reason for which the objectives to be developed in this article are to determine the distribution of the flame detectors, determine the distribution of the deluge sprinklers and design the control diagram of the firefighting system applied to an electrical transformer. Finally, in order to verify if the design shown is optimal, a correlational analysis will be carried out between the pressure and flow present in the system start-up tests.

\section{LITERATURE REVIEW}

The technology framework emphasizes an application innovation for the security and protection services sector, emerging technology helps to provide smart solutions in the aspect of smart city development. An intelligent emergency response system for fire risks in electrical substations is designed and implemented with standards that prioritize immediate rescue operations [13].
The purpose in the detection and automatic extinction of Fire, with watchdog timer technology (WDT) is to produce a reset of the PIC microcontroller every certain period of time, thereby restarting the execution of the program, in order to prevent the device from being blocked (for example, due to some failure in the execution of the program) or remain in a very long wait for a certain event that does not occur (for example, in an infinite loop). During normal operation, the watchdog timer (known in Spanish as the watchdog) causes the PIC to reset at the end of the WDT period. The reset can be avoided if the watch dog timer is reset by executing the CLRWDT instruction before the end of its period. If the device is in Sleep mode, the watch dog timer causes the PIC to wake up and continue normal operation (without resetting), this is known as WDT wake-up. The user has the possibility of using a prescaler for the watchdog timer (16-bit prescaler) and for Timer 0 (8-bit prescaler) at the same time [9].

Likewise, the flame sensor consists of an emitter, a detector with an associative circuit. The emitter consists of an infrared (IR) light emitting diode and the detector consists of an infrared photodiode that detects infrared light that has the same wavelength as the wavelength emitted by IR LEDs. The basic principle involved in the operation of the sensor is the energy of the photons striking the electrons so that the resistance of the circuit changes accordingly [25].

As long as the photodiode detects IR light, the resistance and the corresponding output voltage will change in proportion to the magnitude of IR light received. By this detection sensor flame can often respond very quickly and give accurate measurement. This sensor is designed in such a way that it ignores constant background IR radiation because it is present in all environments. Instead, it is designed to detect sudden changes in IR radiation. To avoid false detections [25].

\section{RESEARCH METHODOLOGY}

\section{A. Research Method, Level and Design}

The research method used is quantitative, because the research seeks to establish a relationship between the operating conditions on quantitative variables, such as the pressure and flow values, obtained in the performance tests from the implementation of the design described. 


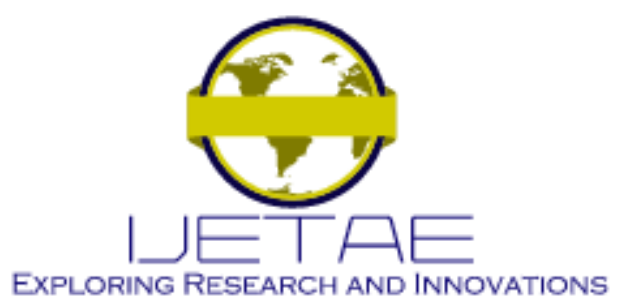

International Journal of Emerging Technology and Advanced Engineering

Website: www.ijetae.com (E-ISSN 2250-2459, Scopus Indexed, ISO 9001:2008 Certified Journal, Volume 11, Issue 11, November 2021)

Regarding the level of investigation, it is correlational since it seeks to establish the intensity of association or relationship between the flow and pressure variables of the automatic fire fighting system. Likewise, the research design is quasi-experimental because the design of the automatic fire detection and extinction system responds to a pre-determined procedure, which is supported by international standards and procedures such as NFPA 13 and 14, which establish the criteria to define the composition and distribution of components (type and distribution of: flame detectors, sprinklers and alarm devices); however, the experimental part focuses on the test of operation of the control system based on the timer watch-dog circuit.

\section{DESCRIPTION AND DEVELOPMENT}

\section{A. Criticality analysis}

As an initial part of the development of the automatic detection and extinction system, an analysis of the assessment of hazards and probabilities of failure of the Assets was carried out, in order to calculate the total risk. Active systems are those that help preserve the availability of the substation's electrical system. In table 1, the risk levels for active systems are specified, also in table 2, the risk analysis of the assets is shown.

TABLE 1

RISK LEVEL FOR ASSETS

\begin{tabular}{|c|c|}
\hline Risk level & Rank \\
\hline Low level (L) & From 0 to 0.59 \\
\hline Medium Level (M) & From 0.60 to 0.69 \\
\hline High level (H) & From 0.70 to 0.79 \\
\hline Extremely high level (EH) & From 0.80 to 1 \\
\hline
\end{tabular}

TABLE 2

ASSET RISK ASSESSMENT

\begin{tabular}{|c|c|c|c|c|c|c|c|c|c|c|c|c|}
\hline Assets & 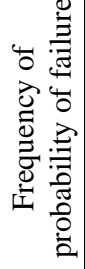 & 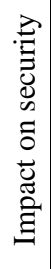 & 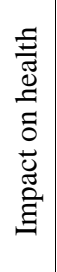 & 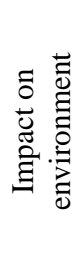 & 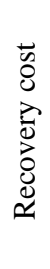 & 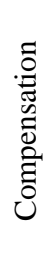 & 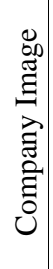 & 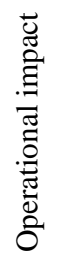 & 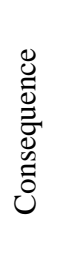 & $\frac{u}{a}$ & 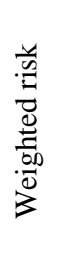 & $\frac{\vec{d}}{\vec{d}}$ \\
\hline Power transformer & 0.38 & 4 & 2 & 4 & 4 & 4 & 4 & 4 & 3.47 & 1.30 & 1 & (EH) \\
\hline Switches & 0.40 & 2 & 3 & 4 & 4 & 3 & 4 & 3 & 3.10 & 1.24 & 0.96 & (EH) \\
\hline Protection relay & 0.50 & 4 & 2 & 1 & 2 & 2 & 4 & 2 & 2.48 & 1.24 & 0.95 & (EH) \\
\hline Static Reactive Power Compensators (SVC) & 0.50 & 2 & 2 & 1 & 2 & 2 & 1 & 1 & 1.63 & 0.81 & 0.63 & (H) \\
\hline Trainers Bank & 0.50 & 2 & 2 & 1 & 2 & 1 & 1 & 1 & 1.47 & 0.74 & 0.57 & (H) \\
\hline Lightning rod & 0.38 & 2 & 2 & 1 & 1 & 1 & 2 & 3 & 1.76 & 0.66 & 0.51 & (H) \\
\hline Compressed air system & 0.50 & 1 & 2 & 1 & 1 & 1 & 1 & 1 & 1.27 & 0.63 & 0.49 & (H) \\
\hline battery bank & 0.38 & 2 & 2 & 2 & 2 & 1 & 1 & 1 & 1.63 & 0.61 & 0.47 & (H) \\
\hline Disconnectors & 0.38 & 2 & 2 & 1 & 1 & 1 & 1 & 1 & 1.46 & 0.55 & 0.42 & (H) \\
\hline Voltage and current measuring equipment & 0.25 & 2 & 2 & 1 & 1 & 1 & 1 & 1 & 1.46 & 0.37 & 0.28 & (M) \\
\hline Auxiliary services & 0.25 & 2 & 2 & 1 & 1 & 1 & 1 & 1 & 1.46 & 0.37 & 0.28 & (M) \\
\hline Bar service & 0.13 & 1 & 2 & 1 & 1 & 1 & 1 & 1 & 1.26 & 0.16 & 0.12 & (L) \\
\hline
\end{tabular}




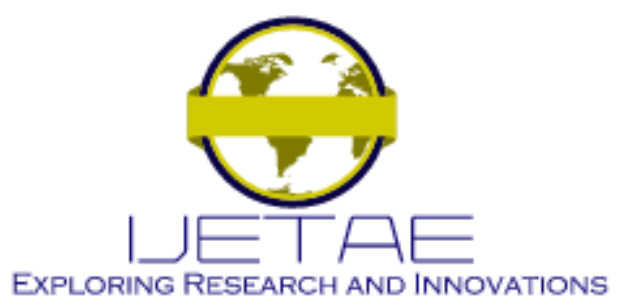

International Journal of Emerging Technology and Advanced Engineering

Website: www.ijetae.com (E-ISSN 2250-2459, Scopus Indexed, ISO 9001:2008 Certified Journal, Volume 11, Issue 11, November 2021)

As can be seen in table 2, there are three assets with an extremely high level of risk, in which the power transformer is above $80 \%$ of the weighted risk, which is why it is the asset on which to focus protection against fire.

\section{B. Description of the extinguishing and detection system}

The automatic fire detection and extinction system is developed in order to protect the $220 / 33 \mathrm{kV}, 225 / 265$ MVA power transformer, quickly detect the fire and transmit the news to initiate the extinction and evacuation of the substation, if necessary.

In the fire suppression system, it is composed of a deluge system, carbon steel pipes, groove joints, deluge valves and fittings, spray nozzles, water tank and a pumping system. The water spray deluge system was designed in accordance with the provisions of NPFA 15, in order to ensure the risk and avoid a possible deflagration that affects the structure or other components of the substation.
This system is actuated by a deluge valve model DV5, diaphragm TYPE, DN40 TO DN200 (1-1/2" to 8") with electrical activation coming from the detection panel, prior to a fire check. In addition, it is composed of a rolled steel water storage tank, a pressurization pump, a set of SCH-40 pipes and galvanized steel pipes, a deluge valve, open nozzle and conical discharge sprinklers.

The design of the wet network of the power transformer is defined as Class III, according to point 5-3.4 of the NFPA 14 Edition 2000 (combined handling for people and firefighters). According to chapter 5-9.1.2 "Hydraulic Calculation Procedure" of NFPA 14 or chapter 4-2.1 "Water Supply" of NFPA 850 Edition 1996. In the substation, water networks are used against fire of the automatic type, that is to say at all times the automatic pumping system filled with pressurized water will be found to protect the power transformers.

In Fig. 1, the isometric detail of the deluge system and sprinkler distribution (From section A-H), which surround the transformer to prevent the spread of the fire in case it is detected, is shown.

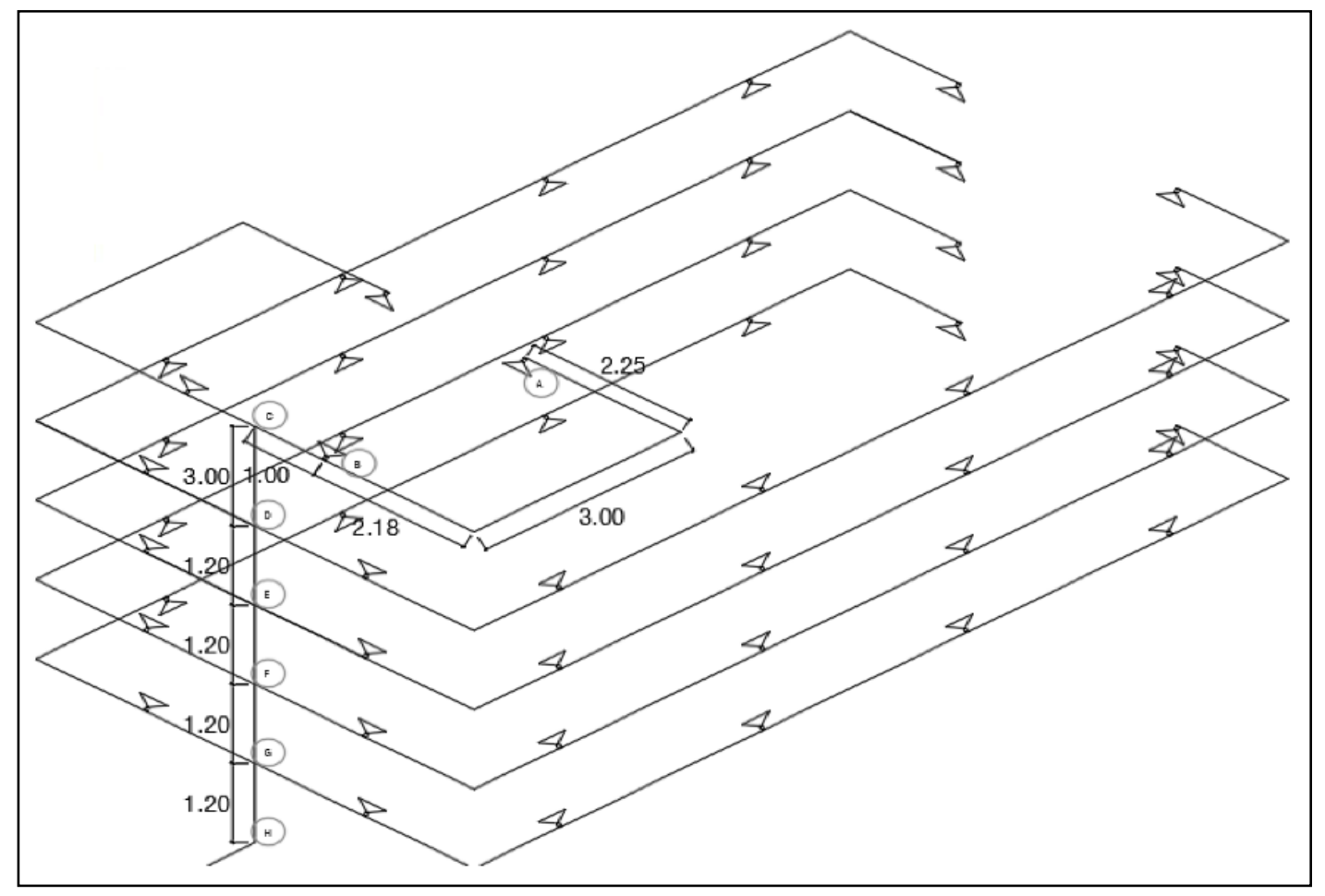

Fig. 1. Isometric detail of the deluge system and sprinkler distribution. 


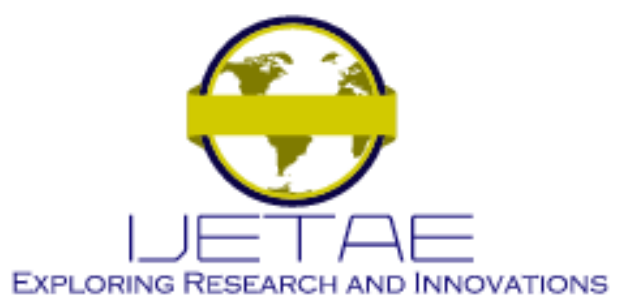

International Journal of Emerging Technology and Advanced Engineering

Website: www.ijetae.com (E-ISSN 2250-2459, Scopus Indexed, ISO 9001:2008 Certified Journal, Volume 11, Issue 11, November 2021)

On the other hand, the automatic detection system is composed of thermal detectors, manual alarm buttons, UV / IR camera, microprocessor of the fire detection panel, battery power source and a fire detection panel (PDI), which has the function of centralizing the supervision and detecting the operation of the detection devices, as well as operating and identifying the alarm devices (sirens and lights) of each zone of the control panel. The PDI directly controls the smart devices integrated into the system. In addition, its programmable logic identifies all the signals of the operational status of all the fire protection systems installed in the substation.

In addition, the PDI must have its own power supply for emergencies, using batteries with its own charger. The panel will automatically connect the batteries in the event of a normal power failure or a voltage drop below $85 \%$ of the nominal value for more than thirty (30) seconds. Once the normal power supply is restored, this emergency power should be automatically disconnected, resuming normal power.

Within the thermal detectors there are ionic and thermovelocimetric Smoke detectors, due to their high response speed. The detection circuit consists of an infrared light-emitting diode (IR-LED) and a light-detecting photodiode.
Under normal conditions the light transmitted by the emitter is deflected from the detector photodiode and scattered through the smoke chamber in a controlled pattern. When the smoke enters the chamber, the light emitted by the IR-LED is scattered by the small smoke particles and is received by the photodiode. The sensitivity of the detectors is programmed by software through the panel of the detection system.

Likewise, the 'Honeywell' brand flame or flame detector is sized for temperatures from $110^{\circ} \mathrm{C}-40^{\circ} \mathrm{C}$ to $+85^{\circ} \mathrm{C}$, at a detection distance greater than $60 \mathrm{~m}$ (200 feet). The FS24X detector features the latest generation Triple IR (IR/IR/ IR/Visible) multispectrum technology for advanced technology electro-optical fire detectors. In addition, they have infrared technology, which allows the detection of all types of fires, generated by hydrocarbons or nonhydrocarbons, in all weather conditions.

In Fig. 2 the installation of the flame detectors (S1 and S2) is shown, whose location is not greater than $70^{\circ} \mathrm{C}$, thus avoiding the incident rays of the sun and the failed detections of the outbreak of fire, the distance of the profiles where the detectors were placed, allow to have a protection radius of $60 \mathrm{~m}$ that completely covers the power transformer.

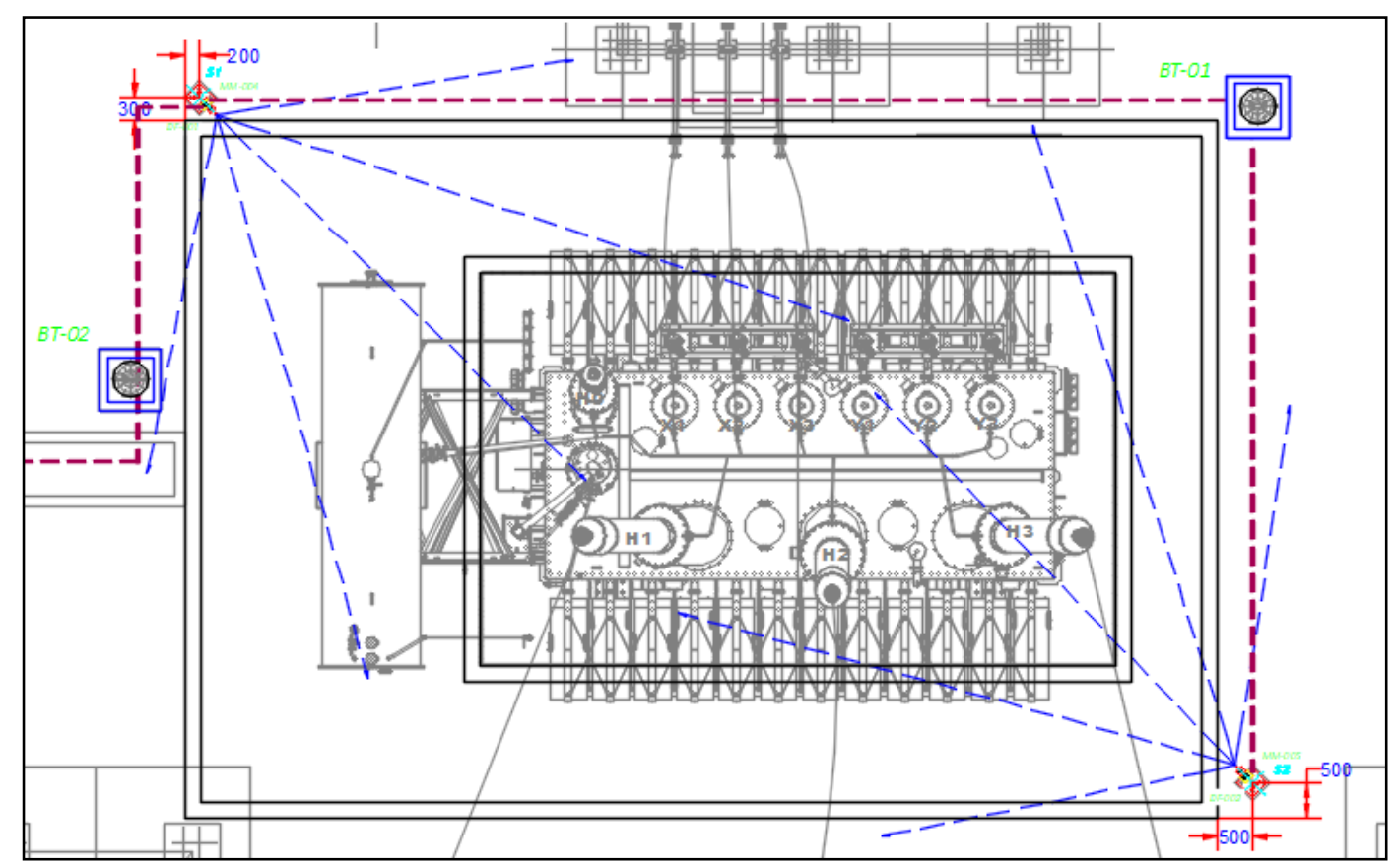

Fig. 2. Flame detector location. 


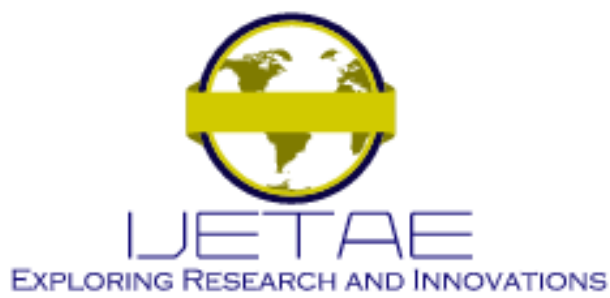

International Journal of Emerging Technology and Advanced Engineering Website: www.ijetae.com (E-ISSN 2250-2459, Scopus Indexed, ISO 9001:2008 Certified Journal, Volume 11, Issue 11, November 2021)

As indicated, the automatic detection system has a stateof-the-art, high-speed microprocessor, which communicates through a monitor with all external interfaces, in the microprocessor of the fire detection panel a EPROM for the system program file, a non-volatile memory for the special programs file and a timer watchdog circuit, which detects and reports any failure in the microprocessor. The substation will have $220 \mathrm{~V}, 50 \mathrm{~Hz}$ general power circuits, which can be used for the normal power supply of the system.

Thus, when the onset of the fire is detected through the detection system, the control center is activated, which in turn sends a signal to the solenoid valves of the damaged transformer, and this in turn opens the checkpoint starting extinction.
Once the control station has been triggered, the pressure in the tank will drop and upon reaching the set value, the pressure switch located in the tank sends an electrical signal to the control unit and this in turn activates the solenoid valve located on the Argon collector, which discharges the gas, to maintain the required pressure until complete extinction. If an extinction trip button is activated, the transformer assigned to that transformer extinguishes immediately.

In Fig. 3, the control diagram is shown, where the fire alarm control panel (FACP), the release service fire alarm control unit (RSFACU), the monitoring module (MM), flow detector (WF), abort switch (DL), flame detection system (DF), deluge valve (SOV), siren (XHA) and manual station output (HA). 


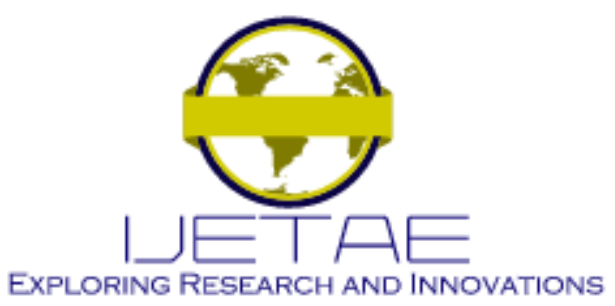

International Journal of Emerging Technology and Advanced Engineering Website: www.ijetae.com (E-ISSN 2250-2459, Scopus Indexed, ISO 9001:2008 Certified Journal, Volume 11, Issue 11, November 2021)

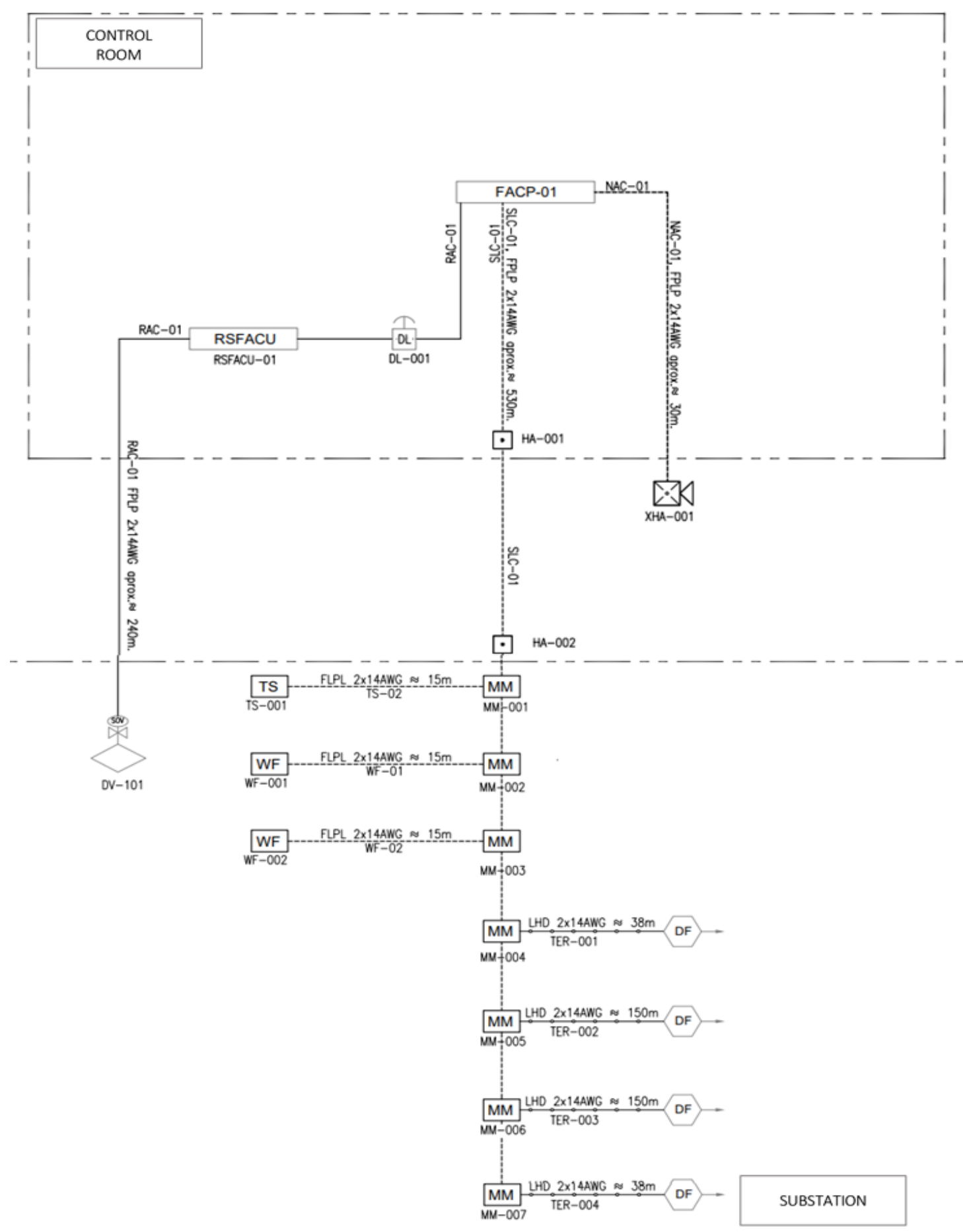

Fig. 3. Automatic fire detection and extinguishing system control diagram. 


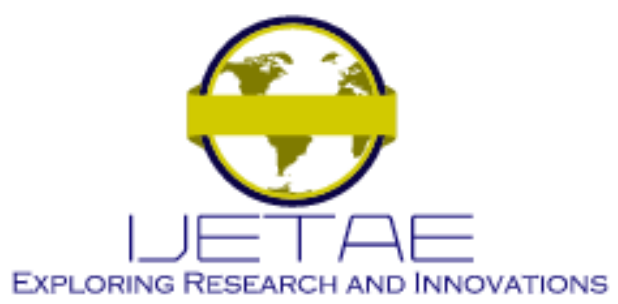

International Journal of Emerging Technology and Advanced Engineering Website: www.ijetae.com (E-ISSN 2250-2459, Scopus Indexed, ISO 9001:2008 Certified Journal, Volume 11, Issue 11, November 2021)

\section{Description of the control and automation system}

In order to establish a logical drive relationship between the sensors and actuators of the fire protection system, of the electrical transformer, fig. 4 shows the configuration of the process inputs and outputs through the TIA PORTAL programming software, of the logic controller programmable PLC Siemens 1200.
It is possible to show the sensors and actuators used in order to achieve that the system responds automatically to the actuation of the sprinklers and valves at an optimal pressure and flow rate for the process.

\begin{tabular}{|c|c|c|c|c|c|c|c|c|c|c|}
\hline \multicolumn{11}{|c|}{ Variables PLC } \\
\hline & & Nombre & Tabla de variables & Tipo de datos & Dirección & Rema... & Acces... & Escrib... & Visibl... & Comentario \\
\hline 1 & (ख) & pressure sensor & Tabla de variables $\mathrm{e}$. & Real & \%MDO & $\square$ & $\square$ & $\nabla$ & $\nabla$ & \\
\hline 2 & (201 & flow sensor & Tabla de variables e. & Real & \%MD4 & $\square$ & $\nabla$ & $\nabla$ & $\nabla$ & \\
\hline 3 & 미 & flow mark & Tabla de variables e. & Real & \%MD8 & $\square$ & $\square$ & $\nabla$ & $\square$ & \\
\hline 4 & 四 & pressure mark & Tabla de variables e. & Real & $\% M D 12$ & $\square$ & $\nabla$ & $\nabla$ & $\square$ & \\
\hline 5 & - खा & pressure sensor input & Tabla de variables e. & Int & \%|W16 & $\square$ & $\nabla$ & $\nabla$ & $\nabla$ & \\
\hline 6 & 四 & flow sensor input & Tabla de variables $\mathrm{e}$. & Int & \%IW18 & $\square$ & $\nabla$ & $\nabla$ & $\nabla$ & \\
\hline 7 & 四 & fire detector input & Tabla de variables $\mathrm{e}$. & Int & $\%$ IW20 & $\square$ & $\nabla$ & $\square$ & $\nabla$ & \\
\hline 8 & 四 & fire mark & Tabla de variables e. & Real & $\% M D 22$ & $\square$ & $\nabla$ & $\nabla$ & $\square$ & \\
\hline 9 & 四 & fire detector & Tabla de variables $\mathrm{e}$. & Real & \%MD26 & $\square$ & $\nabla$ & $\nabla$ & $\nabla$ & \\
\hline 10 & 四 & Automatic system & Tabla de variables $\mathrm{e}$. & Bool & $\% \mathrm{M} 30.0$ & $\square$ & $\nabla$ & $\nabla$ & $\square$ & \\
\hline 11 & - ख & manual system & Tabla de variables e. & Bool & $\% \mathrm{M} 30.2$ & $\square$ & $\nabla$ & $\nabla$ & $\square$ & \\
\hline 12 & ख & fire switcher & Tabla de variables e. & Bool & $\% 10.0$ & $\square$ & $\nabla$ & $\nabla$ & $\nabla$ & \\
\hline 13 & 四 & manual push button & Tabla de variables $\mathrm{e}$. & Bool & $\% 10.1$ & $\square$ & $\nabla$ & $\nabla$ & $\nabla$ & \\
\hline 14 & 四 & pumps & Tabla de variables e. & Bool & $\% Q 0.0$ & $\square$ & $\nabla$ & $\nabla$ & $\nabla$ & \\
\hline 15 & 四 & fire siren & Tabla de variables e. & Bool & $\% Q 0.1$ & $\square$ & $\nabla$ & $\nabla$ & $\nabla$ & \\
\hline 16 & 四 & SPRINKLERS & Tabla de variables e. & Bool & $\% M 30.1$ & $\square$ & $\square$ & $\square$ & $\square$ & \\
\hline
\end{tabular}

Fig. 4. Table of sensors and actuators considered in the control and automation stage

Regarding the flow sensors (logical address: IW18), it is digitized from 0 to 27648 through the Normx block, then it is scaled from 0 to 1200 GPM, through the SCALEX block (MD4 output) for its respective work; also the 1200 GPM value is the maximum value in the data box.
Likewise, the pressure sensors (IW16) have to be digitized (0 to 27648) in the Normx block, then it is scaled (0 to 1200 GPM) with the SCALEX block (MD0 output) for their respective work, the value 80 PSI is the maximum value of the data box. As evidence of the above, fig. 5 shows the first segment of the logic controller programming, in which the pressure and flow sensors are scaled. 


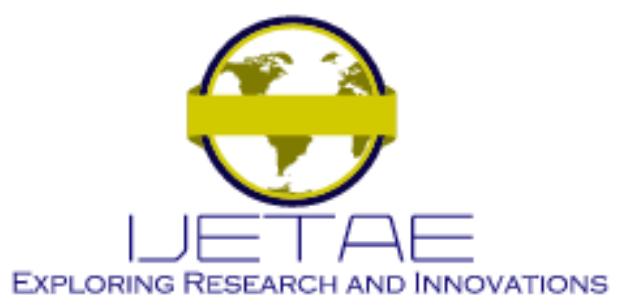

International Journal of Emerging Technology and Advanced Engineering Website: www.ijetae.com (E-ISSN 2250-2459, Scopus Indexed, ISO 9001:2008 Certified Journal, Volume 11, Issue 11, November 2021)

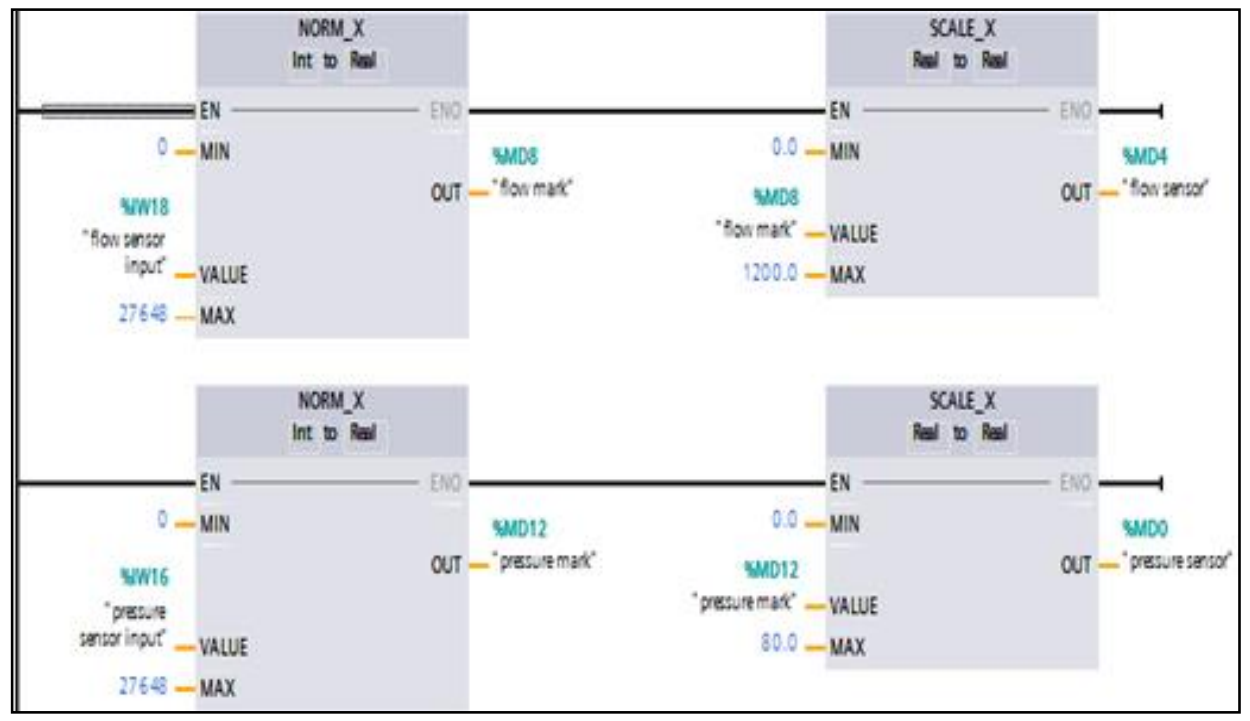

Fig. 5. First Segment of Logic Controller Programming: Scaling of Pressure and Flow Sensor Signals

With respect to the fire detector, in fig. 6, the second segment of the programming is shown, in which the logical address IW20 is established, in which the scaling from 0 to 27648 is carried out, through the Normx block; then it is scaled from 0 to 5 micrometers, with the SCALEX block, whose logical output address is MD26, for its respective work, the value $1200 \mathrm{GPM}$ is the maximum value of the data box.

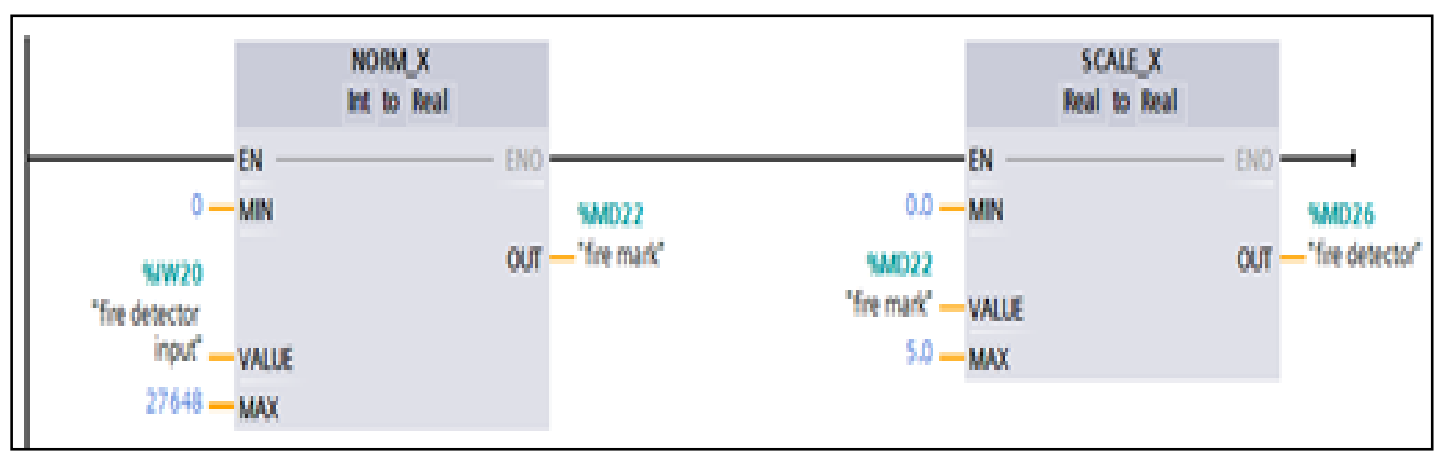

Fig. 6. Second Segment of Logic Controller Programming: Electro-Optic Sensor Scaling

In fig. 7 , it is shown in the supervision and control system through SCADA, in which the pressure sensor shows a value of 60.6 PSI, and the flow sensor shows 53.4
GPM; thus also the electro-optical sensor shows a value of 1 micrometer when detecting the fire, activating the water pump, the sprinkler and the deluge valve. 


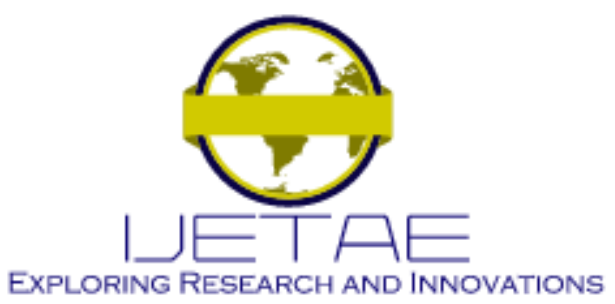

International Journal of Emerging Technology and Advanced Engineering Website: www.ijetae.com (E-ISSN 2250-2459, Scopus Indexed, ISO 9001:2008 Certified Journal, Volume 11, Issue 11, November 2021)

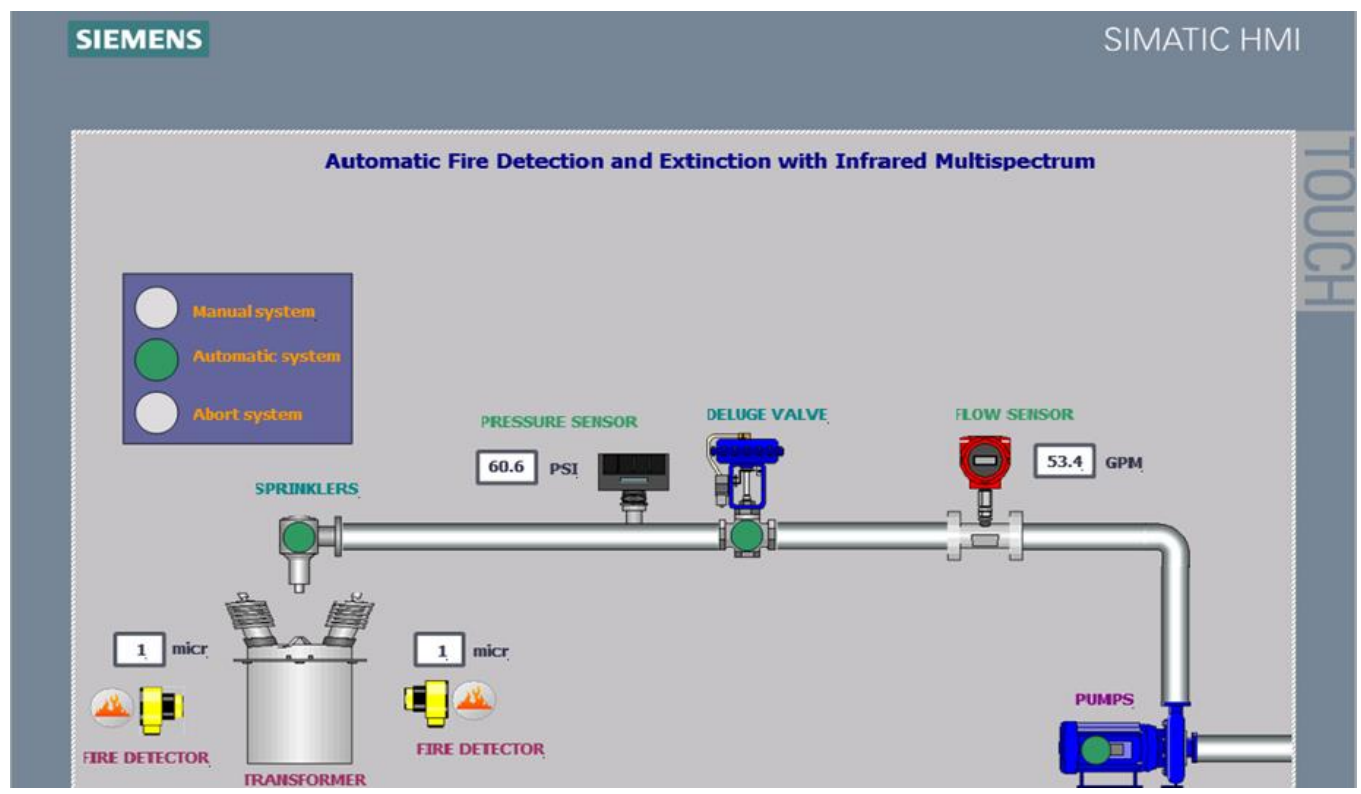

Fig. 7. Evidence of the functioning and operation of the supervision and control system, case: 60.6 PSI and 53.4 GPM

In fig. 8, the pressure sensor shows a value of 66.8 PSI, the flow sensor 559.2 GPM and the electro-optical sensors 2 micrometers, automatically turning on the water pump, sprinkler and deluge valve.

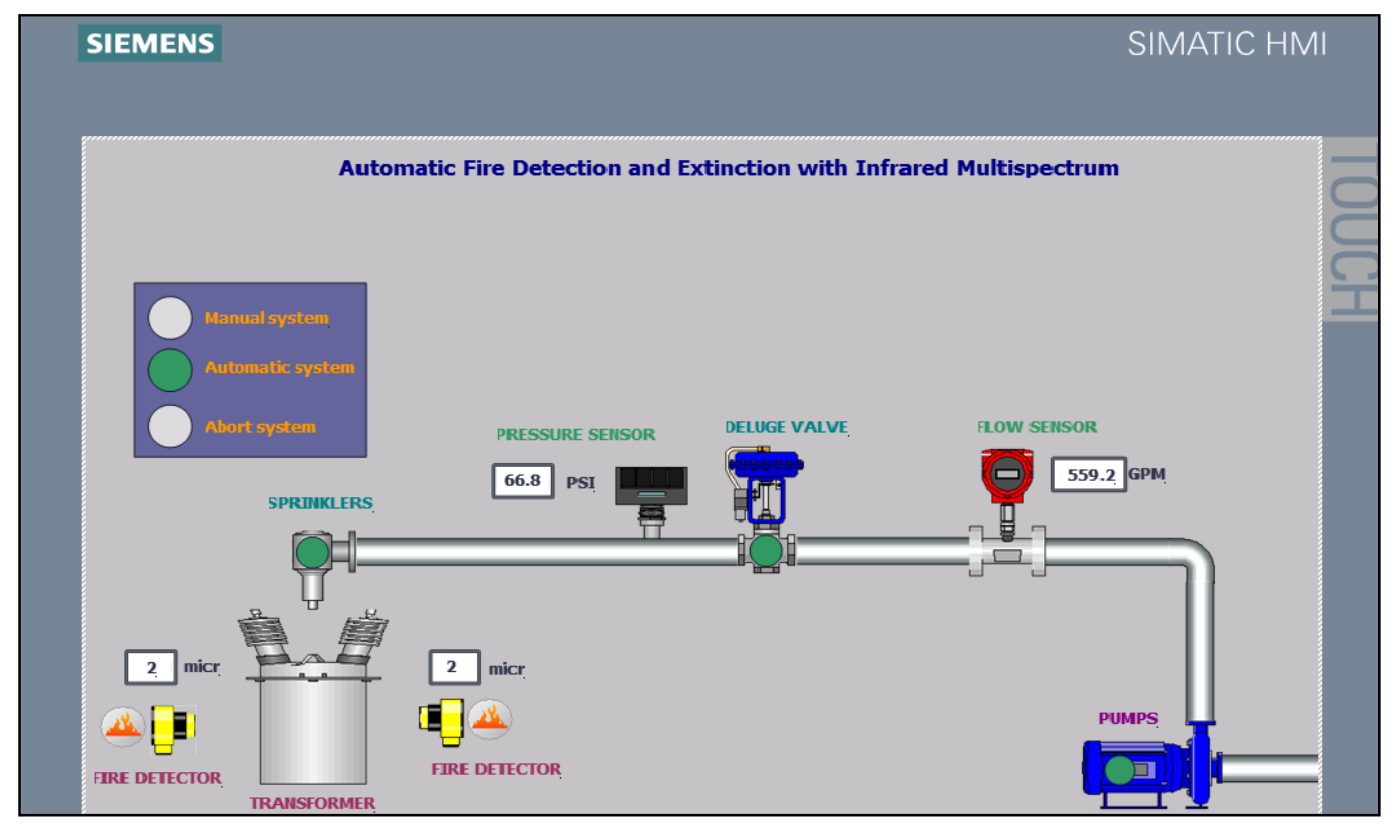

Fig. 8. Evidence of the functioning and operation of the supervision and control system, case: 66.8 PSI and 559.2 GPM 


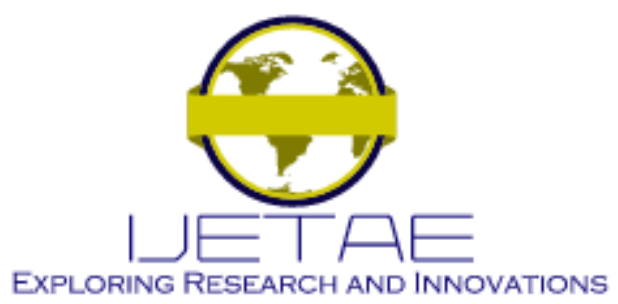

International Journal of Emerging Technology and Advanced Engineering

Website: www.ijetae.com (E-ISSN 2250-2459, Scopus Indexed, ISO 9001:2008 Certified Journal, Volume 11, Issue 11, November 2021)

\section{RESULTS AND DISCUSSION}

\section{A. Results}

In Fig. 9, it can be seen that, as a result of the implementation of the design described in the previous section, with respect to the automatic fire detection and extinction system; that, when subjected to tests of operability and functioning of the deluge sprinklers in response to the activation of the flame detectors, the pressure and flow measured in the different sections of the firefighting system show a relationship with a coefficient of determination $\mathrm{R}^{2}$ equal to 0.991 . This result represents that the design is optimal, evidencing feasibility from the operational and functional point of view.

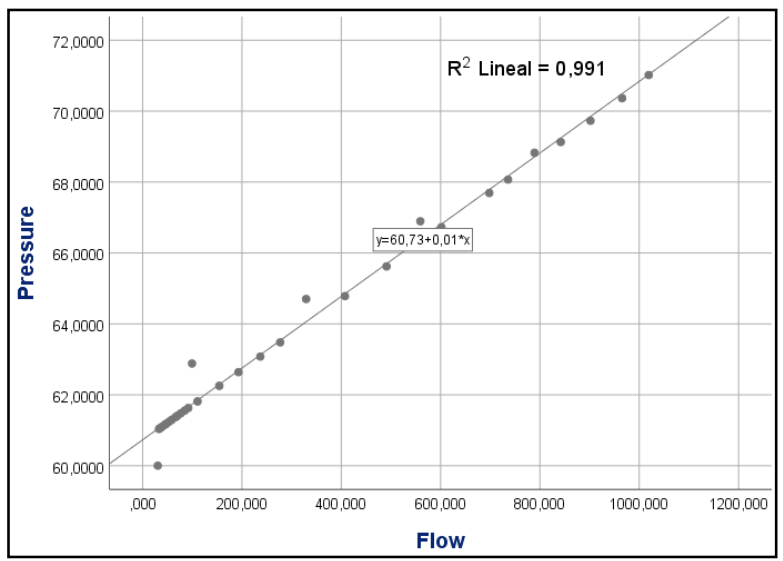

Fig. 9. Linear relationship between pressure and flow of deluge sprinklers

Table 3 shows the values of the coefficient of determination $\mathrm{R}^{2}$ and the coefficient of relation $\mathrm{R}$ between the pressure and the flow of the different sections of the firefighting system, it should be noted that the statistical software SPSS V25 was used for this analysis.

TABLE 3

LINEAR RELATIONSHIP MODEL

\begin{tabular}{|c|c|c|c|}
\hline Model & $\mathrm{R}$ & R squared & $\begin{array}{c}\text { Standard error of the } \\
\text { estimate }\end{array}$ \\
\hline 1 & 0.995 & 0.991 & 32.600195 \\
\hline
\end{tabular}

As can be seen, in table III, the value of the determination coefficient $\mathrm{R}^{2}$ shows a $99.1 \%$ relationship between the pressure variable and the flow variable, likewise, the correlation coefficient $\mathrm{R}$ or Pearson's coefficient, indicates a high level of 0.995 relationship between the variables under analysis. Likewise, the standard error value is less than the mean, which indicates an accurate estimate of the collected data.

\section{B. Dicussion}

The development of the automatic fire extinguishing and detection system, its operability and operation are corroborated, through the optimal behavior of the pressure and flow variables, these results reinforce the rapid extinguishing and detection response to a fire to initiate the evacuation of the substation, if necessary and protect all operators.

Similarly, in [2], an automation was developed using S71200 PLC, for the Fire System of an Electrical Substation, when performing the corresponding tests, it was confirmed that the operating parameters presented normal distribution, in this way correct operation was guaranteed of the firefighting system of the Electrical Substation.

As indicated in [7] the extinguishing system can also alert the user to the presence of a fire, through the Favoriot platform. In this work, the Arduino Uno technology is used to control all the devices and the WiFi shield acts as a means to interconnect devices with the network so that the smoke sensor data can be read on the Favoriot platform. These detection and extinction systems using automatic technologies allow the user to carry out a preliminary rescue action to save people and avoid irreparable consequences.

These results are similar to those indicated in [6] where a prototype of a monitoring and control system for a fire extinguishing system is developed, implemented through SCADA, in which the operational parameters of the extinguishing system are monitored, These parameters are pressure and flow, the values of the parameters are periodically controlled automatically by a frequency variator, when performing the correlation test between the parameters to be monitored, a Pearson coefficient of 0.977 and 0.983 will be determined. 


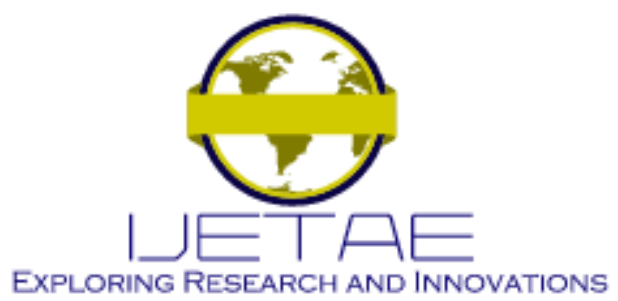

International Journal of Emerging Technology and Advanced Engineering

Website: www.ijetae.com (E-ISSN 2250-2459, Scopus Indexed, ISO 9001:2008 Certified Journal, Volume 11, Issue 11, November 2021)

In [11] it is noted that for emergency response to be in real time, IoT improves the way first responders provide emergency managers with the up-to-date information and communication necessary to make use of those assets. So an intelligent integrated emergency response system for fire risks using a standardized IoT structure, by means of a flame detection sensor, smoke detection sensor (MQ-5), flammable gas detection sensor and a GPS module, which are able to detect danger and alert local emergency rescue organizations, are the new era of transformation to modify the cost-effective quality of services.

Likewise, in [12] it is pointed out that, due to global warming, the risk of starting fires mechanically increases, so the proposed system is based on the collection of data from wireless sensor networks using artificial intelligence, more particularly Deep Learning (DL). The combination of such a system based on the Internet of Things (IoT) concept is made up of a wide range of Area Network (LPWAN), fixed or mobile sensors and a good deep learning model. When carrying out the corresponding evaluations, the system showed the viability of an autonomous system in real time.

As stated in [13] today, automation plays an important role in human life, device automation allows users to control different devices by providing a security system such as door control, temperature and fire detection.

In [17] it is pointed out that early detection of the risk of fire is of vital importance, therefore the characteristics of the sensors used are decisive to discover the onset of fire in real time, as well as to improve scalability and reduce the risk of fire cost of the sensor network. As the author indicates, sensors for infrared and thermal emissions (physical variable) have a high sensitivity that facilitates detection from long distances.

In the same way, what was developed is related to what was indicated in [14], where a fire alert system was developed, using Arduino Mega technology and the GSM SIM 900 module, with which, through programming and interconnection between these components, a fire alert signal can be sent through text messages to a mobile device, finding the relevance of this research in its rapid response, thus finding a coefficient $\mathrm{R}^{2}$ of 0.989 .

\section{CONCLUSIONS}

It is concluded that the automatic fire extinguishing and detection system consists of a deluge system with sprayed water, which will be activated by a detection system with flame sensors, this system has Infrared Multispectrum Electro-Optical Technology and will be controlled through the Timer Watch-Dog, which will automatically detect and report any failure in the state-of-the-art microprocessor.

By subjecting the automatic fire detection and extinguishing system to operational and functional tests, an optimal response was obtained from the deluge sprinklers, by means of the pressure and flow parameters, also processing these data by means of the SPSS, a determination coefficient $\mathrm{R}^{2}$ equal to 0.991 , which represents that the design is optimal, evidencing feasibility from the operational and functional point of view. For this reason, the objective of quickly detecting and extinguishing the fire is fulfilled in order to protect the substation operators and the most critical asset which is the 220/33 $\mathrm{KV}$ power transformer.

\section{Acknowledgment}

Thanks to the National Technological University of Lima Sur

\section{REFERENCES}

[1] Antonov, I., Velichkova, R., Antonov, S., Grozdanov, K., Uzunova M. and El Abbassi I. 2017. Fire extinguishing system in large underground garages. Advances in Science, Technology and Engineering Systems Journal, vol. 2, n. 3, pp. 221-226.

[2] Atalaya, O., Santillan D. and Choque, M. 2019. Fire System for an Automated Electrical Substation via Programmable Logic Controller. Advances in Science, Technology and Engineering Systems Journal, vol. 4, n. 6, pp. 353-359.

[3] Kareem, H. 2019. Embedded real-time system for detecting leakage of the gas used in iraqi kitchens. Indonesian Journal of Electrical Engineering and Computer Science, vol. 14, n. 3, pp. 1171-1176.

[4] Hahnemann, A., Correa, C. and Rabbani, E. 2017. Fire safety assessment: alternative method applied to Brazilian buildings. Journal of the Latin American Association for Quality Control, Pathology and Construction Recovery, vol. 7 n.2, pp. 186-199.

[5] Roslan, A. and Baharom, R. 2020. Advanced gas leakage, fire and power supply failure monitoring system. Indonesian Journal of Electrical Engineering and Computer Science, vol. 17, n. 1, pp. 222-227. 


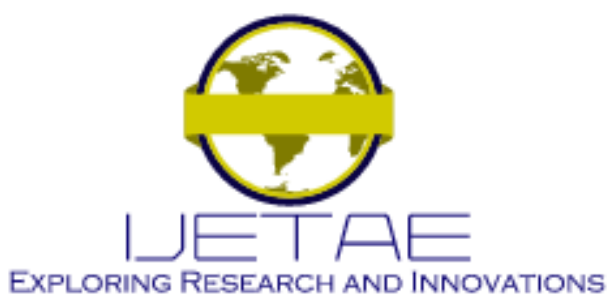

International Journal of Emerging Technology and Advanced Engineering

Website: www.ijetae.com (E-ISSN 2250-2459, Scopus Indexed, ISO 9001:2008 Certified Journal, Volume 11, Issue 11, November 2021)

[6] Chamorro-Atalaya, O., Arce-Santillan, D., Diaz-Leyva, T. and DiazChoque, M. 2021. Supervision and control by SCADA of an automated fire system. Indonesian Journal of Electrical Engineering and Computer Science, vol. 21, n. 1, pp. 92-100.

[7] Suparman, M. A. and Jong, S. L. 2019. Automatic smoke detection system with favoriot platform using internet of things (IoT). Indonesian Journal of Electrical Engineering and Computer Science, vol. 15 , n. 2, pp. 1102-1108.

[8] Park J. K. and Kim, J. 2021. Smart fire monitoring system with remote control using ZigBee network. Indonesian Journal of Electrical Engineering and Computer Science, vol. 21, n. 2, pp. 1132-1139.

[9] Molano, J. and Rodriguez, L. 2017. Design of the fire extinguishing and detection system for the technological faculty of the Francisco José Caldas District University, in accordance with the NFPA and NSR-10 standards. Thesis. Jose Francisco Jose de Caldas District University. Colombia.

[10] Jiménez, G. A. 2018. Analysis of electronic alarm, detection and automatic fire extinguishing systems in new multipurpose buildings in Colombia. Thesis. Militar University of New Granada. Colombia.

[11] Benzekri, W., El Moussaoui A. and Berrajaa, M. 2020. Early Forest Fire Detection System using Wireless Sensor Network and Deep Learning. International Journal Efficient Smart Emergency Response System for Fire Hazards using IoT of Advanced Computer Science and Aplications (IJACSA), vol.11, n. 5, pp. 496-503.

[12] Chituru, D. O., Tamunoene K. A. and Sabastine N. 2020. Semi Automatic Detection and Monitoring of Surface Water Anomaly in Offshore Oil Mining Lease 59 in Nigeria. International Journal of Emerging Technology and Advanced Engineering, vol.10, n. 1, pp. 32-48.

[13] Chamorro-Atalaya, O. and Arce-Santillan, D. 2020. Fire alert system through text messages, with arduino mega technology and GSM SIM 900 module. Indonesian Journal of Electrical Engineering and Computer Science, vol. 18, n. 3, pp. 1215-1221.

[14] Yang, F., Yang, Q., Liu, X. and Wang, P. 2015. Modelling for Forest Fire Evolution based on the Energy Accumulation and Release. International Journal of Advanced Computer Science and Aplications (IJACSA), vol.6, n. 9, pp. 38-45.

[15] Díaz-Delgado, R. and Ruíz-Ramos, J. 2019. Remote Sensing in the Characterization of the Fire and Effects on Vegetation. Academy of Social and Environmental Sciences of Andalusia Journal, vol. 1, no.1, pp.131-146.
[16] Hernandez-Hostaller, N. 2016. Evaluation of sensor technologies for early detection of forest fires. Technology on the Move, vol. 29, n.4, pp.123-138.

[17] Aliff, M. Sami, N. S. and Zainal, A. 2019. Development of Fire Fighting Robot (QRob). International Journal of Advanced Computer Science and Aplications (IJACSA), vol.10, n. 1, pp. 142147.

[18] Duarte, H. V. and Donadon, L. V. 2020. Frequency-based Damage Detection Method using FRFs in High Frequency. International Journal of Emerging Technology and Advanced Engineering, vol.10, n. 1, pp. 49-61.

[19] Carbo, R. V. and Suarez, V. A. 2020. Design of a manual-automatic $\mathrm{CO} 2$ extinction system for the rooms of transformer, panels and fuses of block D of Salesian Polytecchnic. Thesis. Salesian Polytechnic University of Ecuador. Ecuador.

[20] Nadal, J. G. 2018. Design, automation and control of the Facilities of a Sports Center. Thesis. Higher Technical School of Engineering, Spain.

[21] Chuvieco, E. 2019. Forest fire detection and analysis from Satellites and Remote Sensing. Journal of the Royal Academy of Exact Physical and Natural Sciences, vol. 103, n.1, pp.173-182.

[22] Bailón, C. and Díaz, A. F. 2016. Integrated Processors Practices Project: Arduino-based Self-Balancing Robot. Teaching and Learning Computer Engineering, vol. 1, n.5, pp.159-106.

[23] Espinoza, F. S. and Martínez, Z. B. 2016. Application Loader for Microcontroller ATMEGA328P Searching take Advantage of the Resources of a card Arduino. Educational Tracks, vol.120, n.1, pp. 1348-1366.

[24] Memon, K. F., Mahar, J. A., Shaikh, H., Ali, H. A. and Surahio, F. A. 2017. GSM based Android Application: Appliances Automation and Security Control System using Arduino. International Journal of Advanced Computer Science and Aplications (IJACSA), vol.8, n. 2, pp. 206-210.

[25] Maguluri, L. P., Srinivasarao, T., Syamala, M., Ragupathy R. and Nalini, N. J. 2018. Efficient Smart Emergency Response System for Fire Hazards using IoT. International Journal of Advanced Computer Science and Aplications (IJACSA), vol.9, n. 1, pp. 314-320. 